\title{
BIOPRO-Sim: A benchmark simulation model for bio-manufacturing processes
}

\author{
Mansouri, Seyed Soheil
}

Publication date:

2019

Document Version

Publisher's PDF, also known as Version of record

Link back to DTU Orbit

Citation (APA):

Mansouri, S. S. (2019). BIOPRO-Sim: A benchmark simulation model for bio-manufacturing processes. 27. Abstract from 1st International Young Professionals Conference on Process Engineering (YCPE 2019), Magdeburg, Germany.

\section{General rights}

Copyright and moral rights for the publications made accessible in the public portal are retained by the authors and/or other copyright owners and it is a condition of accessing publications that users recognise and abide by the legal requirements associated with these rights.

- Users may download and print one copy of any publication from the public portal for the purpose of private study or research.

- You may not further distribute the material or use it for any profit-making activity or commercial gain

- You may freely distribute the URL identifying the publication in the public portal

If you believe that this document breaches copyright please contact us providing details, and we will remove access to the work immediately and investigate your claim 


\section{Keynote Lecture}

\section{BIOPRO-Sim: A benchmark simulation model for bio-manufacturing processes}

\section{$\underline{\text { Seyed Soheil Mansouri }}$}

\section{Technical University of Denmark, Lyngby, Denmark}

In this work, a bio-pharmaceutical production process of an API, lovastatin, is developed through a systematic process synthesis and design approach, and then modelled, implemented and simulated. In course of model implementation the experience from the real world processes from BIOPRO project is brought into the context. BIOPRO is a large Danish academia-industry cluster to foster process improvement for bio-manufacturing process (www.biopro.nu). The developed simulation is intended to be used as benchmark process model as it captures the generic process dynamics of a bio-pharmaceutical process, and as such it is well-suited to use as a test problem to evaluate different processing scenarios, optimization approaches and control strategies in presence of uncertainty. The synthesis and design of the process model is realized through a methodology based on two complimentary steps that can be applied individually or in conjunction, and is adopted to synthesize the upstream and downstream processing pathway. As such, the process model can be operated either as a whole, or as an individual upstream or downstream process. 